standable on their facts. ${ }^{49}$ Thus the Court is not yet irrevocably committed to an equal protection rationale. A full dress opinion by the Supreme Court embodying a due process rationale would not only avert needless increases in the cost of judicial administration, but would also enable the courts, state and federal, ${ }^{50}$ to establish procedures which would allow meritorious indigent appeals to be heard while dispensing with those which are frivolous.

${ }^{49}$ There is language in Griffin which is readily applicable to a due process interpretation of that case: "Surely no one would contend that either a State or the Federal Government could constitutionally provide that defendants unable to pay court costs in advance should be denied the right to plead not guilty or to defend themselves in court. Such a law would make the constitutional promise of a fair trial a worthless thing. Notice, the right to be heard, and the right to counsel would under such circumstances be meaningless promises to the poor. . . There is no meaningful distinction between a rule which would deny the poor the right to defend themselves in a trial court and one which effectively denies the poor and adequate appellate review accorded to all who have money enough to pay the costs in advance." Griffin v. Illinois, 351 U.S. 12, 17-18 (1956).

${ }^{50}$ The Supreme Court has power to balance these interests in the federal courts by virtue of its authority under the Criminal Appeals Rules Act, 62 Stat. 846 (1948), as amended, 18 U.S.C.A. $\$ 3771$ (1958). Since this general regulatory power does not extend to state procedures, it is likely that federal courts will be held to stricter standards than are state courts in in forma pauperis proceedings.

\title{
FOREIGN DONEE'S WIL: REQUIREMENT OF PROBATE AT DONOR'S DOMICILE
}

When, after a foreign donee's ${ }^{1}$ testamentary exercise of a power of appointment granted by a domiciliary donor, a trustee is faced with the duty of disposing with the corpus of a trust, two competing rules of law often appear to frustrate the trustee's attempt to determine the validity of the donee's exercise of the power. ${ }^{2}$ Courts in a majority of jurisdictions, in the absence of any clear expression of intention by the donor, will construe a donor's will granting a power of appointment "exercisable by will"' to require that the donee's instru-

${ }^{1}$ As used herein the term "donee" refers to a donee who neither is domiciled nor has property, other than the power of appointment if the power should be deemed property, in the donor's domicile.

${ }^{2}$ It is clear that where both the trustee and the property subject to appointment are located at the donor's domicile the courts of that state can make an independent determination as to whether the powers have been validly exercised, and may completely disregard the decrees of the donee's domicile concerning the donee's will in so far as such decrees purport to determine the validity and effect of the attempted exercise of the powers. Blount v. Walker, 134 U.S. 607 (1890); In re Harriman's Estate, 124 Misc. 320, 208 N.Y.S. 672 (Surr.Ct., 1924). See also Mulford, The Conflict of Laws and Powers of Appointment, 87 U. of Pa. L. Rev. 403, 418-19 (1939).

3 This comment is concerned only with those grants of powers wherein the donor specifies neither a particular statute of wills with which the donee's instrument must comply nor whether the donee's instrument must be probated to effectively exercise the power. The language usually employed is "as [the donee] shall by will appoint" [Wachovia Trust Co. v. Doughton, 272 U.S. 567, 572 (1926)], "by her last will and testament in writing" [Sewall v. Wilmer, 132 Mass. 131, 132 (1882)], or, "as per his last will and testament" [In re Sloan's Estate, 7 Cal.App.2d 319, 321, 46 P.2d 1007, 1008 (1935)]. 
ment comply with the statute of wills of either the donor's or donee's domicile. ${ }^{4}$ At the same time, some of these jurisdictions ${ }^{5}$ seem to impose the incongruous requirement that the foreign donee's instrument purporting to be a will be admitted to probate at the donor's domicile before it can be construed by a court of construction at the donor's domicile. ${ }^{6}$ This requirement appears to stem from the rigidity of application of the same rule by English courts. ${ }^{7}$ Its tenure is probably perpetuated by the commonly held notion that wills must be probated prior to their being received in a court of construction for interpretation. ${ }^{8}$

The first difficulty created by the requirement of probate is encountered whether or not the donee's instrument complies with the statute of wills at the donor's domicile. It is questionable whether the probate courts in some states would be statutorily competent to probate the donee's will. ${ }^{9}$ For example, the Illinois Probate Act ${ }^{10}$ can be read as limiting the competency of probate courts to the probating of wills of only those non-resident testators who owned

4 See cases cited in Conflict of Laws as to Exercise of Power of Appointment, 150 A.L.R. 519, 523-31 (1944). See also Mulford, op. cit. supra note 2, at 418-19.

5 E.g., New York: compare In re Harriman's Estate, 124 Mjsc. 320, 208N.Y.S. 672 (Surr.Ct., 1924), with Ward v. Standard, 82 App.Div. 386, 81 N.Y.S. 906 (1903); Maryland: compare Prince de Bearn v. Winans, 111 Md. 434, 74 Atl. 626 (1909), with Olivet v. Whitworth, 82 Md. 258, 33 Atl. 723 (1896).

SIn re Harriman's Estate, 124 Misc. 320, 208 N.Y.S. 672 (Surr.Ct., 1924); Prince de Bearn v. Winans, 111 Md. 434, 74 Atl. 626 (1909); Mulford, op. cit. supra note 2, at 419; Exercise of Testamentary Power of Appointment Over Personal Property: The Effect of a Difference in the Domiciles of Donor and Donee in Determining Its Validity, 38 Harv. L. Rev. 661, 667 n.27 (1925).

7 In re Harriman's Estate, 124 Misc. 320, 208 N.Y.S. 672 (Surr.Ct., 1924); Tatnal v. Hankey, 2 Moo. P.C. 342, 350 (1838); 1 Williams, Executors \$183 (13th ed., 1953).

${ }^{8}$ See In re Harriman's Estate, 124 Mísc. 320, 208 N.Y.S. 672 (Surr.Ct., 1924); Castro v. Richardson, 18 Cal. 478 (1861). But see In re Sloan's Estate, 7 Cal. App.2d 319, 46 P.2d 1007 (1935).

9 E.g., Ill.Rev.Stat. (1957) c. 3, \$206; and cf. Davis v. Upson, 230 Ill. 327,82 N.E. 824 (1909); N.Y. Surr.Ct. Act (Gilbert-Bliss, 1953) $\$ \$ 45,46,47$, and cf. In re Bradford's Will, 159 Misc. 482, 288 N.Y.S. 153 (Surr.Ct., 1936), and Mackean's Will, 259 App.Div. 728, 18, N.Y.S.2d 230 (1940); Mass. Laws Ann. (1955) c. 215, §3, and cf. Gordon v. Shea, 300 Mass. 95, 14 N.E.2d 105 (1938); Calif. Pro. Code Ann. (1959) $\$ \$ 301,360$, and cf. Glassford Estate, 114 Cal.App.2d 181, 249 P.2d 908 (1952), and Estrem Estate, 16 Cal.2d 563, 197 P.2d 36 (1940); Ore.Rev.Stat. (1957) $\$ 115.140$, and cf. Thomas Kay Woolen Mill Co. v. Sprague, 259 Fed. 338 (D.Ore., 1919); 20 Pa.Stat.Ann. (Purdon, 1950) $\$ 320.301,1840.301$ (Supp. Purdon, 1958). and cf. In re Lang's Estate, 301 Pa. 429, 152 Atl. 570 (1930); S.C. Laws Ann. (1952) \$\$15-401, 15-446, and cf. In re Mayo's Estate, 60 S.C. 401, 38 S.E. 634 (1900). See generally Glassford Estate, 114 Cal.App.2d 181, 249 P.2d 908 (1952), annotated at 34 A.L.R.2d 1259 (1954).

${ }^{10}$ Ill.Rev.Stat. (1957) c. 3, $\$ 206:$ "When the will of a testator is probated or when the estate of a decedent is administered in this State, the probate or the administration shall be in the probate court of the county determined as follows: (a) In the county where his mansion house is situated. (b) If he has no mansion house in this state, in the county where he has a known place of residence. (c) If he has neither a mansion house nor a known place of residence in this state, in the county wherein the greater portion of his real estate is located. (d) If he has no mansion house, no known place of residence, and no real estate in this state, in the county where the greater part of his personal estate is located at the time of his death." 
property situated in Illinois. ${ }^{\text {.1 }}$ The question whether a power of appointment constitutes "property" within the terms of such statutes has apparently never been discussed in a reported opinion..$^{12} \mathrm{It}$ is clear, however, that the trust res is not the property of the donee but the donor ${ }^{13}$ and that powers of appointment are not a property interest which creditors of the donee can attach. ${ }^{14}$ Thus, the impossibility of invoking the jurisdiction of a probate court in the donor's domicile may be an insuperable obstacle to meeting the requirement.

A second obstacle, encountered if the probate court in the donor's domicile has jurisdiction to probate the donee's instrument, arises when the donee's instrument, in conformity with the requirements of the donor's will, would comply with the statute of wills of the donee's domicile but not that of the donor's domicile. Since such an instrument could not be probated, the requirement of probate before construction would prevent any judicial determination of the validity of the donee's attempted exercise of the power. In such a situation, the trustee would be compelled to hazard a distribution based upon a nonjudicial interpretation of the donor's instrument. ${ }^{15}$ An unsuccessful attempt by the trustee to probate the donee's instrument at the donor's domicile would, more than likely, induce the trustee to conclude that the attempted exercise of the power was invalid. In such case, the trustee would probably proceed to distribute the trust res either to the default beneficiaries or, in lieu of a default clause in the donor's will, to the donor's residuary legatees or heirs. As a result, the aggrieved appointees could probably charge the trustee with wrongful dis-

11 Ill.Rev.Stat. (1957) c. $3, \S 206$. This section was intended by its drafters to be a restatement of section 11 of the Wills Act of 1872 (IIl.Rev.Stat. [1939] c. 148, \$13), Ill. State Bar Ass'n., Ill.Pro.Act Ann. (James ed., 1940) 64-65. This was construed to deny to Illinois probate courts jurisdiction to probate the wills of foreign testators who owned no property situated in Illinois. Davis v. Upson, 230 Ill. 327, 82 N.E. 824 (1909); In re Estate of Nielson, 320 Ill.App. $655,658,52$ N.E.2d 44, 45 (1943). A power of appointment would not appear to be property within the meaning of Ill. Rev. Stat. 1957 c. 3, \$206; IIl. State Bar Ass'n., Ill.Pro. Act Ann. (James ed., 1940) 65-66; Simes, Devolution of Title to Appointed Property, 22 Ill. L. Rev. 480, 488 n.24 (1928).

12 But see In re Bradford's Will, 159 Misc. 482,486, 288 N.Y.S. 153, 159 (Surr.Ct., 1936), containing a dictum which negatively implies, among other implications, that a power of appointment constitutes property in the donor's domicile for probate purposes.

${ }^{13}$ Blount v. Walker, 134 U.S. 607 (1890). See Simes, op. cit. supra note 11.

14 In re Scott's Estate, 158 Pa.Super. 138, 44 A.2d 323 (1945), aff'd 353 Pa. 575, 46 A.2d 174 (1946); Mercantile Trust Co. v. Bergdorf \& Goodman Co., 167 Md. 158, 173 Atl. 31 (1934); Gillman v. Bell, 99 IIl. 144 (1881). Special powers may also be exercised in derogation of creditors' liens. Johnson v. Shriver, 121 Cölo. 397,216 P.2d 653 (1950); Connor v. O'Hara, $188 \mathrm{Md}$. 527, 53 A.2d 33 (1947). See also authorities collected in Simes, op. cit. supra note 11, at 496 n. 52 .

${ }^{15}$ Such a determination would be particularly hazardous in view of the fact that the trustee is absolutely liable to distribute the trust res to the correct beneficiaries. Good faith, including reliance on the decree of a probate court interpreting the donor's will, probably will not absolve him from that liability. Prince de Bearn v. Winans, 111 Md. 434, 74 Atl. 626 (1909); 2 Scott on Trusts $\$ \$ 226,226.1$ (2d ed., 1956); 4 Bogert, Trusts and Trustees $\$ 184$ (1948); Trusts: Distribution of Trust Income-Liability for Payments to an Unqualified Beneficiary, 7 Hastings L. J. 111 (1955). Contra: Rodgers v. Herron, 226 S.C. 317, 85 S.E.2d 104 (1954). 
tribution by initiating an action in a court of general jurisdiction and urging the court to accept the decree admitting the donee's instrument to probate at the donee's domicile as evidence of the fact that the donee's instrument had been labeled a "will.".16

This result, anomalous where the donee's instrument would ultimately be found to be in compliance with the intent of the donor, is compelled only by the requirement that the donee's will be initially admitted to probate at the donor's domicile. This result is avoided by courts in some donor's domiciles by accepting the probate decree of the donee's domicile as sufficient to establish the donee's instrument as a "will."17 The result could also be avoided by allowing a trustee to apply directly to a court of construction for the purpose of procuring the court's determination as to whether the instrument purporting to exercise the power is a compliance with the requirement's for the validity of the exercise as set forth in the donor's will. That a court of construction is the proper forum for the determination of all issues with respect to the donee's exercise of the power is a proposition which can be supported on several grounds.

First, the ultimate issue in cases involving the validity of exercises of powers of appointment is not whether the instrument purporting to exercise the power has been labelled by a probate court as a "will," but whether the donee's instrument is the kind of instrument which the donor would have intended to be utilized in exercising the power. ${ }^{18}$ In other words, the problem initially involves interpretation of those provisions of the donor's will which relate to the exercise of the power. Only when the court of construction has concluded, either from the express terms of the donor's will or from an inference supplied by a rule of construction invoked in the absence of any clear expression by the donor, ${ }^{19}$ that the power must have been exercised in a will, does the question whether the donee's instrument complies with the requirements of some statute of wills arise. ${ }^{20}$ Thus the chronological sequence of issues would seem to support the suggested procedure. However, the present procedure which requires probate

${ }^{16}$ See Adger v. Kirk, 116 S.C. 301, 180 S.E. 97 (1921).

${ }^{17}$ Ibid.; In re Smith's Will, 57 N.Y.S.2d 189 (Surr.Ct., 1945). Care in drafting instruments granting powers of appointment could also avoid this problem. One draftsman has at least partially solved the trustee's problem by inserting the following clause: "In determining whether, in what manner and to what extent a power of appointment hereunder has been exercised by will, the trustee may act in reliance upon a court order admitting an instrument to probate as the will of the holder of the power or finding that he died intestate. . ." City National Bank \& Trust Co. of Chicago, Will and Trust Forms 24 (2d ed., 1958).

${ }_{18}$ Pitman v. Pitman, 314 Mass. 465, 471-72, 50 N.E.2d 69, 73 (1943), annotated at 150 A.L.R. 519, 523-24 (1944).

19 Pitman v. Pitman, 314 Mass. 465,50 N.E.2d 69 (1943).

20 "[T]he essential inquiry in all cases of this kind is-First, what is the mode prescribed by the donor of the power for its execution: and, second, whether such mode has been strictly complied with. Now, in this case, the mode prescribed by the donor of the power is expressed in these words-'By her last will and testament duly executed'-and the controlling question is, what was the intent of [the donor] in using those words?" Blount v. Walker, 28 S.C. 545, $548-49,6$ S.E. 558 (1888). 
initially is perhaps explainable: since the provisions granting powers of appointment in most donor's wills evidence no clear expression of the donor's intention with respect to whether the donee's instrument must comply with the requirements of a particular statute of wills, ${ }^{21}$ there is an almost perpetually recurrent invocation of the rule of construction based upon the inference that the donor intended compliance with either the donor's or the donee's domicile's statute of wills. This recurrence, along with the courts' failure to articulate a purpose for requiring the imprimatur of a probate court, ${ }^{22}$ has resulted in an apparently mechanical application of the rule of construction.

Second, it would appear that the only purpose which probating serves is to insure that the donee's instrument was voluntarily executed by the donee without any element of fraud or undue influence in the execution..$^{23}$ If this is the purpose of the requirement, ${ }^{24}$ it would seem that a court of construction could just as easily receive direct evidence, as contrasted with evidence in the form of a probate decree, in cases involving a power of appointment exercisable by testamentary instrument as in cases of other forms of exercise. For example, should the donor provide that the power disposing of the trust res be presently exercisable rather than exercisable by a testamentary instrument, a court

${ }^{21}$ See note 3 supra.

22 The primary function of a probate court is to provide, after probate of the will, for administration upon the estate. Ill.Rev.Stat. (1957) c. 3, \$205; Ill. State Bar Ass'n., Ill.Pro.Act Ann. (James ed., 1940) 63-64; In re Bradford's Will, 159 Misc. 482, 485, 288 N.Y.S. 153, 157 (Surr.Ct., 1936). It should be observed that administration upon an estate is not required in the foreign donee situation discussed herein.

${ }^{23}$ This point is perhaps most clearly illustrated by several New York cases wherein the court of construction's insistence upon a probated will does not appear to be based on adhesion to any procedural requirement. It should be noted in connection with these cases that the New York Decedents Estate Law has received a construction similar to that given the Illinois Probate Act, see notes 9 and 11 supra. In re Harriman's Estate, 124 Misc. 320, 208 N.Y.S. 672 (Surr.Ct., 1924), the leading case cited in support of the requirement of probate at the donor's domicile, involved the instrument of a California donee which purported to exercise a power of appointment created by the will of a New York donor. Although California courts had refused to probate the donee's will, the New York Surrogate Court indicated its willingness to recognize the validity of the exercise of the power if "the instrument purporting to exercise the power [was] first [probated in New York]." Id., at 327 and 679. However, when read in the light radiated by In re Smith's Will, 57 N.Y.S.2d 189 (Surr.Ct., 1945), Harriman's Estate requires merely that the donee's will be probated somewhere. In Smith's Will the validity of a New Jersey donee's exercise of powers granted by a New York donor was attacked on the ground that the donee's will had not been probated in New York. Since the donee's instrument had, however, been probated in New Jersey, the New York Surrogate Court, distinguishing Harriman's Estate, held that "it [was] unnecessary that the will of the donee of the power be probated in [New York]." Id., at 190. The Surrogate Court "accept[ed] the decree of the foreign court proving the donee's will as a valid testamentary instrument." Id., at 190 . In addition to the New York courts' rejection of probate in New York as a procedural matter, there is language in both cases which indicates that the real concern of the New York courts was for some evidence that the donee's execution was free from fraud and undue influence. In re Harriman's Estate, 124 Misc. 320, 327-28, 208 N.Y.S. 672, 679-80 (Surr.Ct., 1924); In re Smith's Will, 57 N.Y.S.2d 189, 190 (Surr. Ct., 1945).

${ }^{24}$ See note 22 supra. 
would certainly receive direct evidence of the validity of the document ${ }^{25}$ exercising the power, since the document obviously could not be admitted to probate. Such a position was suggested in Sewall v. Wilmer ${ }^{26}$ where the donor provided that the trust res be disposed of as the donee "shall direct ... by ... her last will and testament, . . or by a writing purporting to be her last will ... to be by her duly executed in the presence of ... three credible witnesses. ... ${ }^{\text {s27 }}$ Chief Justice Gray, writing for the Massachusetts Supreme Judicial Court, indicated in a dictum that probate of the writing "purporting to be her last will" would not have been required. ${ }^{28}$ And, although the dictum goes no farther, it could be read to imply that a court construing the donor's will, for the purpose of determining whether the donee's will was in compliance with its provisions, would have received evidence to determine whether the "writing purporting to be her last will and testament" was, as required by the donor's will, "executed [by the donee] in the presence of . . . credible witnesses. . . ."29 Such a determination does not differ, under some wills statutes, from the determination labelled "probate."

${ }^{25}$ The document may be a deed, McGee v. Vandeventer, 326 Ill. 425, 158 N.E. 127 (1927); or a simple note in writing, Goodloe v. Woods, 115 Va. 540, 80 S.E. 108 (1882).

26132 Mass. 131 (1882).

${ }^{27} \mathrm{Id}$., at 132.

${ }^{28}$ Id., at 137.

${ }^{29}$ Id., at 132.

\section{RENDERING UNTO CAESAR: STATE HEALTH REGULATIONS AND THE FREE EXERCISE OF RELIGION}

When state public health regulations have been challenged as an infringement on the free exercise of religion, in violation of the First and Fourteenth Amendments, they have almost uniformly been held constitutional on the basis of four Supreme Court cases which have interpreted the First Amdndment as an absolute protection of "freedom of belief" but not of "freedom of action." The precedent value of these decisions, however, appears to have been greatly diminished by West Virginia Board of Education v. Barnette, ${ }^{2}$ whose impact has not been sufficiently appreciated by state courts. ${ }^{3} \mathrm{It}$ is the purpose of this note to explore the effect of the change in doctrine, manifested by the Supreme Court in the Barnette case, on state power over public health.

\section{I}

In the first case, Reynolds v. United States, ${ }^{4}$ Reynolds, a Mormon, was convicted of the crime of bigamy in the territory of Utah. His defense was that his

1 Cantwell v. Connecticut, 310 U.S. 296 (1940); Jacobson v. Massachusetts, 197 U.S. 11 (1905); Davis v. Beason, 133 U.S. 333 (1890); Reynolds v. United States, 98 U.S. 145 (1878).

2319 U.S. 624 (1943). This case overruled Minnersville School District v. Gobitis, 310 U.S. $586(1940)$.

${ }^{3}$ See Section III infra.

498 U.S. 145 (1878). 